\title{
Human capital quality and the immigrant wage gap
}

Serge Coulombe*, Gilles Grenier and Serge Nadeau

\author{
* Correspondence: Serge. \\ Coulombe@uottawa.ca \\ University of Ottawa, Ottawa, \\ Canada
}

\begin{abstract}
We propose a new methodology for analyzing determinants of the wage gap between immigrants and natives. A Mincerian regression framework is extended to include GDP per capita in an immigrant's country of birth as a proxy for the quality of schooling and work experience acquired in that country. We find that Canadian immigrants' returns to schooling and work experience significantly increase with the GDP per capita of their country of birth. The contribution of quality of schooling and work experience to the immigrant wage gap is also examined. Lower human capital quality completely negates the endowment advantage that immigrants have in the areas of schooling and work experience. Since data on GDP per capita are available for most countries over long periods, the proposed methodology can be applied to analyze immigrant wage gaps for a large set of countries for which common statistics on natives and immigrants are available.
\end{abstract}

JEL codes: J20, J24, J15, J61

Keywords: Wage differentials; Immigrants vs. Canadian natives; Human capital quality; Immigration policies; Work experience; Education

\section{Introduction}

The wage gap between immigrants and natives is a key measure of how well immigrants integrate into an economy, and by extension, of the effectiveness of a country's immigration and labor market policies. The gap can be decomposed into an explained component and an unexplained component. The explained component is the part of the gap that can be attributed to differences in observed skills (mainly schooling and work experience) between immigrants and natives. In the U.S., for example, immigrants have on average fewer years of schooling than natives, which explains to a large extent their lower wages (Card, 2005; Smith 2006).

The unexplained component of the wage gap reflects the extent to which the observed skills of immigrants are not valued as much as those of natives in the host country's labor market. Canada is a good example of how significant the unexplained component can be. Unlike their U.S. counterparts, immigrants in Canada have better observed skills than natives (mainly because of Canada's immigration policy which is based on a point system), but still earn substantially less than them.

To paraphrase Abramovitz (1956) on the Solow residual, the unexplained component can be viewed as a measure of our ignorance. It can be attributed to a variety of factors that cannot be easily measured such as discrimination (Oreopoulos, 2009), institutional rigidities, market failures, or the inability of employers to recognize foreign credentials

C 2014 Coulombe et al.; licensee Springer. This is an Open Access article distributed under the terms of the Creative Commons Attribution License (http://creativecommons.org/licenses/by/4.0), which permits unrestricted use, distribution, and reproduction in any medium, provided the original work is properly credited. 
(Reitz, 2005). The purpose of this paper is to improve our understanding of the determinants of immigrant wages. By doing so, we explain a larger part of the wage gap and thus reduce our ignorance in that regard.

Our approach is based on the hypothesis that the schooling and work experience acquired by immigrants in their country of birth may be of different quality than those acquired by the natives of the host country. Bloom, Grenier and Gunderson (1995), Schaafsma and Sweetman (2001), and Bonikowska, Green and Riddell (2008) all use the difference in quality argument in their analyses of immigrant wages in Canada, and Bratsberg and Terrel (2002) does the same for the U.S. However, our analysis of the immigrant wage gap is novel in that it provides a general methodology that can directly account for the quality of schooling and work experience in immigrant wage regressions.

Differences in human capital quality across immigrants from different countries have been typically measured using the results of cognitive tests (see, for example, Bonikowska, Green and Riddell, 2008; Coulombe and Tremblay, 2009). There are two major problems with this approach. One is data availability. Test scores from the International Adult Literacy and Skills Survey (IALS) are available for only 27 countries and for very few years (in Canada, the last one was conducted in 2003 and the previous one in 1994). The other problem is more fundamental. While it may be suitable to use the results of cognitive tests as measures of schooling quality, it is inappropriate to use them as measures of work experience quality because they are not designed to assess the value of work experience. Indeed, while, for example, a lawyer with 25 years of experience is certainly much more productive for a firm than a recruit who just recently graduated, one can easily envision the former being outperformed by the latter in a cognitive test such as IALS.

The objective of this paper is to propose a methodology that can be applied to analyze immigrant wage gaps for a large set of countries for which common statistics on natives and immigrants are available. This methodology is applied to the case of Canada. Building on the work of Coulombe, Grenier and Nadeau (2014) in a first step, we show how GDP per capita can be used as a cross-country proxy for the quality of schooling and work experience in Mincerian immigrant wage regressions. Essentially, the ratio between the GDP per capita of an immigrant's country of birth and that of Canada, measured at the time of graduation or at the time of immigration, is used as an indicator of schooling quality and of work experience quality and is interacted with the years of schooling and work experience variables.

The approach is appealing for a number of reasons. First, we should expect GDP per capita to be a good indicator of human capital quality as rich countries generally allocate more resources to education and provide better on-the-job learning opportunities-because of their high levels of technology and capital/labor ratios-than poor countries. Second, there is empirical evidence that the returns to schooling and work experience are positively related to a country's GDP per capita (see, for example, Coulombe, Grenier and Nadeau, 2014, and Lagakos et al. 2012). Third, data on GDP are available for most countries in the world and for long periods of time ${ }^{1}$. Finally, unlike in cross-country growth studies, GDP per capita is can be considered as an exogenous variable in an empirical analysis of immigrant earnings.

In a second step, we estimate our wage regression equations using 2006 Canadian census data on male and female immigrants and natives. Results reveal that the returns 
to schooling and work experience significantly increase with the GDP per capita of an immigrant's country of birth, even when incorporating country of birth fixed effects and occupation and industry controls in the regression. In particular, we find that schooling and work experience acquired in a country whose GDP per capita is similar to that of Canada have annual rates of return that are respectively 1.6 and 0.8 percentage point higher than schooling and work experience acquired in a country whose GDP per capita is one-tenth that of Canada (schooling and work experience acquired in India for example).

In a third step, we use a variant of the Blinder-Oaxaca method to decompose the immigrant wage gap into an explained component, an unexplained component and an immigrant specific component that includes human capital quality effects. We find that lower human capital quality completely negates the endowment advantage that immigrants have in the areas of schooling and work experience and is by far the major reason why they earn less than Canadian natives. We also find that after controlling for human capital quality, the unexplained component of the wage gap (which is sometimes associated with labor market discrimination) is reduced by almost 62 percent for male immigrants and virtually eliminated for female immigrants.

The results of the analysis in this paper have important policy implications. Among other things, they suggest that if a country wants to adopt an immigrant selection policy based on a point system such as that of Canada, then for the same number of years of schooling and of work experience, the number of points should vary depending on the assessed quality of those years of schooling and work experience. In particular, more points should be allocated if schooling (especially the highest diploma) and work experience have been acquired in Canada-or in a highly developed country-than if they have been acquired in a less developed country. Another (and possibly more efficient) immigrant selection approach, would be to rely less on the number of years of schooling and of work experience in selecting immigrants, and more on cognitive and professional accreditation tests.

This paper is organized as follows. Section 2 discusses the issue of controlling for human capital quality in studies of the labor market integration of immigrants and justifies the use of GDP per capita as an indicator of human capital quality. Section 3 presents the statistical framework. Section 4 discusses the data used along with summary statistics. Section 5 presents the empirical results and Section 6 concludes.

\section{Controlling for immigrant human capital quality}

When immigrants move to another country, one thing they bring with them is their human capital. Most people would agree in a casual conversation that one year of schooling or of work experience in a very poor country is generally not worth as much as one year of schooling or of work experience in a very rich country. Yet, much of the research on the labor market integration of immigrants ignores this issue; it assumes that one year of schooling or of work experience is worth the same irrespective of where it has been acquired ${ }^{2}$. Beyond casual conversation though, the modern growth literature actually provides ample evidence that an immigrant's schooling and work experience quality may be as important as his or her schooling and work experience quantity in explaining labor market performance in the host country. For example, 
Coulombe, Tremblay, and Marchand (2004) and Hanushek and Woessman (2008) conclude that cognitive skills (which are related to both the quantity and the quality of schooling) are a much better predictor of economic growth than mere school attainment.

Another aspect of immigrant human capital quality is self-selection. Common wisdom is that since immigrants are a self-selected group, they may be "more able and more highly motivated" (Chiswick, 1978, p. 900) than natives. However, self-selection may work the other way around too; for example, Borjas (1987) argues that under certain conditions (e.g., higher income inequality in the source country than in the U.S.), immigrants "need not be drawn from the most able and most ambitious in the country of origin" (Borjas, 1987, p. 551). One way or the other though, self-selection is an issue that must be kept in mind when comparing the returns to skills of immigrants with those of natives.

Beside expediency, one possible reason why so few studies in the labor market integration of immigrants' literature ignore differentials in human capital quality is the lack of widely available human capital quality indices that apply to both education and work experience. As already pointed out, the approach of using cognitive tests suffers from two major drawbacks. First, highly developed and comparable cognitive tests, such as those in IALS, are expensive to do and are available in only a few surveys and for a very limited number of countries. For example, the IALS is done in only 27 countries, and for many countries, too few immigrants are included in the sample. An option is to extrapolate the available test scores to other countries (as in Hanushek and Kimko, 2000), but, as discussed in Sweetman (2004), this can result in measurement errors ${ }^{3}$.

Second, the use of cognitive test scores in assessing the quality of human capital is really only appropriate for the education component ${ }^{4}$. Surveys such as the IALS are designed to evaluate the quality of the education provided by the formal education system or informally by the family network; they are not designed to evaluate the other major component of human capital which is work experience. This point is of particular importance since there are good reasons to believe that the quality of work experience is highly correlated with the development level of a country. Furthermore, in Canadian studies, it is recognized that the work experience acquired in an immigrant's country of birth has a different return than that acquired in the Canadian labor market (Schaafsma and Sweetman, 2001).

Borrowing from Coulombe, Grenier and Nadeau (2014), we propose to use GDP per capita that we interpret as an indicator of human capital quality ${ }^{5}$. A great practical advantage of using GDP per capita instead of other possible quality indicators (such as results of cognitive tests) is that data on GDP per capita across countries are available for most countries in the world over long periods of time. However, there are also several other (more) conceptual reasons for using GDP per capita as an indicator of human capital quality.

Regarding the education component, more and better resources are generally allocated to the education system in countries with higher GDP per capita. For example, although the combined population of Africa and South America is about 35 times that of Canada, only seven universities in Africa and South America are among the top 400 universities in the world, compared with 18 in Canada (according to Times Higher Education, 2012), Similarly, from the works of Arrow (1962) and Romer (1986) 
on learning-by-doing and the works of Erosa, Koreshkova and Restucia (2010) and Manuelli and Seshadri (2010) on the relationship between total factor productivity and human capital accumulation, we should expect work experience to be of higher quality if it has been acquired in a rich country than if it has been acquired in a poor country, as the former typically has a higher capital/labor ratio and is closer to the technological frontier than the latter. Furthermore, as argued by Bloom and Van Reenen $(2007,2010)$, differences in customs, in labor organization and in managerial styles across countries may promote (or discourage) innovative thinking and may therefore have different impacts on human capital quality. Empirical evidence from the economic development literature indicates that GDP per capita is strongly (positively) correlated with the results of cognitive tests (see, for example, Coulombe, Tremblay and Marchand, 2004, Coulombe and Tremblay, 2009, Hanushek and Kimko, 2000 and Hanushek and Woessmann, 2008) and with the returns to work experience (see, for example, Coulombe, Grenier and Nadeau, 2014, and Lagakos et al. 2012) ${ }^{6}$.

Finally, it should be noted that GDP per capita in an immigrant's country of birth can be considered as an exogenous variable in an empirical analysis of immigrant wages in Canada. Of course GDP per capita is determined by a number of factors beside human capital, such as the quality of institutions, level of technology and capital/labor ratio. However, what immigrants bring with them when moving to another country is their human capital-the other factors that determine GDP are left behind.

\section{The statistical framework}

The statistical framework used in this paper is based on the well-known BlinderOaxaca decomposition method (see Blinder, 1973; Oaxaca, 1973). As in Nadeau and Seckin (2010), we allow for the possibility of the wage determination process to be different between immigrant and natives. Let the subscripts $N$ and $I$ respectively denote Native and Immigrant; $S$ denote the number of years of schooling; $X$ denote the number of years of work experience; $y$ denote a vector of other control variables, including a constant term, common to Canadian born individuals and immigrants (a basic specification includes language skill, region of residence and marital status, and an extended specification adds industry and occupation indicators to the above); $z$ denote a vector of country of birth fixed effects; and the overscript $\sim$ denote variables measured in efficiency units (to be explained later). Then the mean log wages of Canadian born workers and immigrant workers can be respectively expressed as

$$
w_{N}=\alpha_{N} \tilde{S}_{N}+\beta_{N 1} \tilde{X}_{N}+\beta_{N 2} \tilde{X}_{N}^{2}+y_{N} \phi_{N}
$$

and

$$
w_{I}=\alpha_{I} \tilde{S}_{I}+\beta_{I 1} \tilde{X}_{I}+\beta_{I 2} \tilde{X}_{I}^{2}+y_{I} \phi_{I}+z \gamma
$$

where all the right-hand side variables are sample means, and the $\alpha, \beta, \phi$ and $\gamma$ are OLS estimated coefficient vectors.

To allow for the quality of education to vary across countries, let $s_{h}$ and $s_{f}$ respectively denote the number of years of schooling spent in the host country and in the birth country $\left(S=s_{h}+s_{f}\right)$; $f_{\text {dip }}$ denote a dichotomous variable that takes on the value of one if an individual's highest diploma was not obtained in the host country and zero otherwise; $q_{s}$ denote an education quality index constructed in such a way that $q_{s}=0$ if the 
q $\delta$ uality of education acquired in an immigrant's birth country is comparable to that acquired in the host country, $q_{s}<0$ if it is lower than that acquired in the host country and $q_{s}>0$ if it is greater than that acquired in the host country. Further, for simplicity, assume that immigrants acquire their years of schooling and their highest diploma either in their birth country or in their host country and that the quality of schooling varies not only with the country where it is acquired but also with the country where the highest diploma is obtained. Thus we specify years of schooling measured in efficiency units as

$$
\tilde{S}=s_{h}+s_{f}\left(\delta_{1}+\delta_{2} q_{s}+\delta_{3} f_{d i p}+\delta_{4} f_{d i p} q_{s}\right)
$$

where $\delta$ is a vector of coefficients.

We model work experience in efficiency units in a similar way. Let $x_{h}$ and $x_{f}$ respectively denote the number of years of experience spent in the host country and in the birth country $\left(X=x_{h}+x_{f}\right) ; q_{x}$ denote a work experience quality index constructed in such a way that $q_{x}=0$ if the quality of experience acquired in an immigrant's birth country is comparable to that acquired in the host country, $q_{x}<0$ if it is lower than that acquired in the host country and $q_{x}>0$ if it is greater than that acquired in the host country. Thus we model years of work experience measured in efficiency units as

$$
\tilde{X}=x_{h}+x_{f}\left(\delta_{5}+\delta_{6} q_{x}\right)
$$

We would expect all the $\delta$ coefficients to be positive except $\delta_{3}$ which we would expect to be negative, so that the same number of years of schooling and of work experience and the same diploma would be worth less (in terms of efficiency units) if acquired in a country that has lower human capital quality than Canada.

Finally, following the discussion in the previous section, we specify the human-capital quality index at a given point in time as:

$$
q_{t}=\ln \left(\frac{G D P c_{f t}}{G D P c_{h t}}\right)
$$

where $G D P c_{f t}$ and $G D P c_{h t}$ respectively denote GDP per capita in an immigrant's birth country and GDP per capita in the host country at time $t$ (smoothed to eliminate the effects of business cycles by taking a ten year moving average - see the Data Appendix). The difference between $q_{s}$ in equation (3) and $q_{x}$ in (4) is that $q_{s}$ is $q_{t}$ measured at the time of graduation, while $q_{x}$ is $q_{t}$ measured at the time of immigration to the host country ${ }^{7}$.

Thus, given equations (3) and (4), if we assume that all natives completed their studies and acquired their work experience in the host country and if we allow the country of birth's GDP to have a direct effect (that is, an effect that is independent of the level of schooling and the level of experience, and that is evaluated at the time of entry of the immigrant), then $\tilde{S}_{N}=S_{N}$ and $\tilde{X}_{N}=X_{N}$, and with some algebra, equations (1) and (2) can be rewritten in reduced form as

$$
w_{N}=\alpha_{N 1} S_{N}+\beta_{N 1} X_{N}+\beta_{N 2} X_{N}^{2}+y_{N} \phi_{N}
$$




$$
\begin{aligned}
& w_{I}=\alpha_{I 1} S_{I}+\theta_{1} q_{x}+\theta_{2} s_{I f}+\theta_{3} s_{I f} q_{s}+\theta_{4} s_{I f} f_{d i p}+\theta_{5} s_{I f} f_{d i p} q_{s} \\
& +\beta_{I 1} X_{I}+\beta_{I 2} X_{I}^{2}+\theta_{6} x_{I f}+\theta_{7} X_{I} x_{I f}+\theta_{8} x_{I f}^{2}+\theta_{9} x_{I f} q_{x}+\theta_{10} X_{I f} x_{I f} q_{x}+\theta_{11} x_{I f}^{2} q_{x}+\theta_{12} x_{I f}^{2} q_{x}^{2} \\
& +y_{I} \phi_{I}+z \gamma
\end{aligned}
$$

where the $\theta$ 's are OLS estimated coefficients and all the right-hand side variables are sample means ${ }^{8}$. Note that $\theta_{1}$ may pick up a self-selection effect (à la Borjas, 1987).

The framework above allows performing a number of tests on the impact of quality of education and of work experience on immigrant wages and, by extension, on the immigrant wage gap. In particular, building on Blinder (1973) and Oaxaca (1973), given (6) and (7) the immigrant wage gap can be decomposed as the sum of six components:

$$
\begin{aligned}
& \left(w_{I}-w_{N}\right)=\left\{\alpha_{N 1}\left(S_{I}-S_{N}\right)+\beta_{N 1}\left(X_{I}-X_{N}\right)+\beta_{N 2}\left(X_{I}^{2}-X_{N}^{2}\right)+\left(y_{I}-y_{N}\right) \phi_{N}\right\} \\
& +\left\{S_{I}\left(\alpha_{I 1}-\alpha_{N 1}\right)+X_{I}\left(\beta_{I 1}-\beta_{N 1}\right)+X_{I}^{2}\left(\beta_{I 2}-\beta_{N 2}\right)+y_{I}\left(\phi_{I}-\phi_{N}\right)\right\} \\
& +\theta_{1} q_{x}+s_{I f}\left\{\theta_{2}+\theta_{3} q_{s}+\theta_{4} f_{d i p}+\theta_{5} f_{d i p} q_{s}\right\} \\
& +\left\{x_{I f}\left(\theta_{6}+\theta_{9} q_{x}\right)+X_{I} x_{I f}\left(\theta_{7}+\theta_{10} q_{x}\right)+x_{I f}^{2}\left(\theta_{8}+\theta_{11} q_{x}+\theta_{12} q_{x}^{2}\right)\right\}+z \gamma
\end{aligned}
$$

The first term in the decomposition (8) is the explained component of the wage gap. This component measures the portion of the wage gap due to differences between the observed attributes of immigrants and those of Canadian born workers, evaluated with the coefficients of the latter. The second term is the unexplained component of the wage gap. The other four terms are the immigrant specific components of the wage gap. The third term is the country of birth's GDP direct effect. The fourth and fifth terms respectively reflect the impact of immigrant quality of education and quality of work experience. The last term reflects the impact of immigrant country of birth fixed effects.

\section{Data and descriptive statistics}

We use data from the Statistics Canada 2006 Census Microdata Masterfile for our analysis. Canada has a relatively large immigrant population, with $20 \%$ of the people being born abroad, and with more than 250,000 new immigrants arriving every year. Through a Point System which emphasizes factors such as education, age, work experience and language ability, Canada's immigration policy clearly gives the priority to skilled immigrants. As a result, the recent cohorts of immigrants have especially high levels of schooling-in fact, higher than the Canadian-born.

The census data provide a very large sample of immigrants, with specific information on their countries of birth. The sample is restricted to men and women aged 18 to 64, who worked full-time full-year in 2005, who were not self-employed and who obtained their highest certificate, degree or diploma either in their country of birth or in Canada. Full-time is defined as 30 hours or more a week and Full-year is defined as 49 weeks or more. The total number of years of schooling is not directly available from the census data and it is imputed based on the highest certificate, degree or diploma (see Table A1 in appendix). For immigrants, the variable Years of schooling in birth country is calculated from the year of birth, the total number of years of schooling, the year when landed immigrant status was first obtained in Canada, and whether the highest certificate, degree or diploma was obtained in Canada. Workers who have not obtained their highest certificate, degree or diploma in either Canada or their country of birth are 
excluded from the samples because there is no way of inferring how many years they have spent studying outside Canada or their birth country 9 .

Potential work experience is defined the usual way, as Age minus Years of schooling minus 6. Canadian born individuals are assumed to have acquired all their work experience in Canada. Immigrants may have obtained their work experience in Canada or in their birth country but not in a third country (as there is no information available to that effect). Years of work experience in birth country is calculated from the year of birth, Potential work experience and the year when landed status was first obtained.

Data on GDP per capita are adjusted for purchasing power parity and come from Heston, Summers and Aten (2009). More details on the variables of our analysis are given in Appendix A.

Table 1 displays summary statistics on Canadian born and immigrant workers in our sample. It is interesting to note that despite being endowed with more years of schooling and work experience, male immigrants earn on average about 4.1 percent less than natives, while the equivalent figure for female immigrants is 3.3 percent. In this paper, we argue that a major reason for the existence of this gap is that the human capital of immigrants in Canada is lower than that of Canadian born.

\section{Empirical results}

In this section, we report estimates of the Canadian born earnings equation (6) and nested versions of the immigrant earnings equation (7), from the most restricted to the least restricted. This allows for the examination of changes in coefficient estimates following the removal of restrictions. The estimated returns to years of schooling and

Table 1 Key Common Average Characteristics of Immigrant and Canadian Born Individuals (2006) ${ }^{\dagger}$

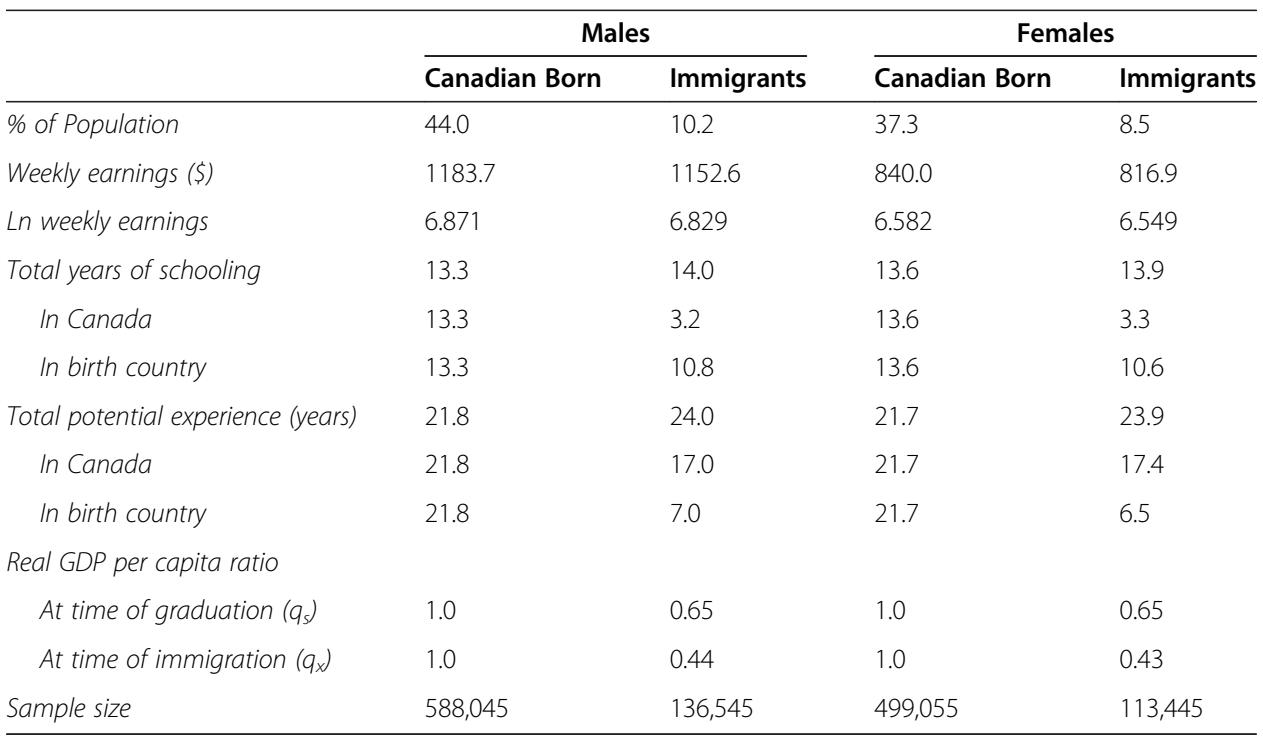

${ }^{\dagger}$ Full-time, full-year working individuals between 18 and 64. Immigrants and Canadian born individuals are restricted to those having obtained their highest diploma in their country of birth. Canadian born individuals are assumed to have acquired all their work experience in Canada. Immigrants are assumed to have acquired their work experience either in their birth country or in Canada.

Source: Calculations from Statistics Canada 2006 census data. 
work experience are reported in Table 2 for males and Table 3 for females. The other estimated coefficients are reported in Table B1 in Appendix B.

\subsection{Base case: No control for human capital quality}

The most restricted case of (7) is when it is assumed that the wage determination process of immigrants is exactly the same as that of Canadian born individuals; that is, when it is assumed that from a human capital point of view, the quality of one year of schooling or work experience acquired in an immigrant's country of birth is the same as that acquired in Canada and that an immigrant's country of birth does not have any influence on the wage determination process. This corresponds to equation (7) with all the $\theta$ 's and the $\gamma$ vector set equal to zero. The results in the column labelled Model 1 in Table 2 and Table 3 show that if such an assumption was correct then the returns to human capital would significantly be lower for immigrants than for Canadian born individuals. For example, for males, the returns to years of schooling and years of work experience (evaluated at zero years of work experience) would respectively be 6.6 percent and 3.5 percent per year for male immigrants compared with 8.0 percent and 4.9 percent per year for their Canadian born counterparts. The results are similar for females.

\subsection{Human capital acquired in Canada vs. Human capital acquired in birth country}

Model 2 in Table 2 and Table 3 is a first step towards distinguishing between the quality of schooling and work experience acquired in Canada and that acquired in an immigrant's country of birth. The difference between this model and Model 1 is that the returns to schooling and to work experience are now allowed to differ by a fixed quantity depending on whether schooling and work experience have been acquired in Canada or outside Canada. This model also allows for country of birth fixed effects. In other words, compared to Model 1, Model 2 relaxes the assumptions $\left(\theta_{2}=\theta_{4}=\theta_{7}=\theta_{8}=\gamma=0\right)$.

Model 2's estimation results strongly support the notion that the quality of schooling and of work experience is perceived by Canadian employers to be lower if these qualifications have been acquired outside Canada. Looking at schooling first, we find from column (3) of Table 2 that all other things equal, a male immigrant earns 0.5 percent less per year of schooling if his schooling (including his highest diploma) has been acquired in his country of birth than if his schooling has been acquired in Canada (the equivalent figure for a female immigrant is 1.0 percent). What seems to be driving this result though is not so much whether schooling is acquired outside Canada, but whether the highest diploma is obtained in Canada. Indeed, this differential is reduced to only 0.1 percent if a male immigrant obtains his highest diploma in Canada instead of in his country of birth (the equivalent figure for a female immigrant is 0.3 percent).

The difference between the marginal return of one year of work experience acquired in Canada and that of one year of work experience acquired in an immigrant's country of birth is even more pronounced: for males and females, the return to one year of work experience acquired in an immigrant's country of birth is about 1.9 percent less than the return to one year of work experience acquired in Canada (or about two-third smaller in relative terms $)^{10}$. 
Table 2 Estimated returns to years of schooling and years of work experience-Males ${ }^{\dagger}$

\begin{tabular}{|c|c|c|c|c|c|c|c|c|c|c|}
\hline \multirow[t]{2}{*}{ Variables } & \multirow[t]{2}{*}{$\begin{array}{l}\text { Canadian } \\
\text { born (1) }\end{array}$} & \multicolumn{2}{|c|}{$\begin{array}{l}\text { Model } 1 \text { (no difference in } \\
\text { quality) }\end{array}$} & \multicolumn{2}{|c|}{$\begin{array}{c}\text { Model } 2 \text { (Model } 1+\text { country of birth schooling }+ \\
\text { country of birth work experience }+ \text { country of birth } \\
\text { fixed effects) }\end{array}$} & \multicolumn{2}{|c|}{$\begin{array}{c}\text { Model } 3 \text { (Model } 2+\text { direct } \\
\text { effect of } q \text { ) }\end{array}$} & \multicolumn{2}{|c|}{$\begin{array}{c}\text { Model } 4 \text { (Model } 3+\text { interaction } \\
\text { effects of } q \text { ) }\end{array}$} & \multirow{2}{*}{$\begin{array}{c}\text { Model 5 } \\
\text { (Model } 4+ \\
\text { occupation } \\
\text { and } \\
\text { industry } \\
\text { indicators) }\end{array}$} \\
\hline & & Immigrants (2) & (2) - (1) & Immigrants (3) & (3) - (1) & Immigrants (4) & (4) - (1) & Immigrants (5) & (5) - (1) & \\
\hline$\overline{a_{1}(S)}$ & $0.080(258)$ & $0.066(108)$ & -0.013 (19.) & 0.068 (96.) & $-0.012(15)$. & $0.068(51)$. & $-0.012(8.8)$ & $0.070(61)$. & $-0.010(8.5)$ & 0.049 (51.) \\
\hline$\theta_{1}\left(q_{1}\right)$ & & & & & & $0.042(6.8)$ & & $-0.005(0.7)$ & & $-0.014(2.2)$ \\
\hline$\theta_{2}\left(s_{f}\right)$ & & & & $-0.001(1.1)$ & & $-.0003(0.3)$ & & $-0.001(0.7)$ & & $.0005(0.6)$ \\
\hline$\theta_{3}\left(s_{f} q_{s}\right)$ & & & & & & & & $0.002(5.7)$ & & $0.003(8.0)$ \\
\hline$\theta_{4}\left(s_{f} f_{\text {dip }}\right)$ & & & & $-0.004(12)$. & & $-0.004(9.6)$ & & $0.002(4.1)$ & & $0.002(4.6)$ \\
\hline$\theta_{5}\left(s_{f} f_{d i p} q_{s}\right)$ & & & & & & & & 0.004 (12.) & & 0.003 (11.) \\
\hline$\beta_{1}(X)$ & $0.049(184)$ & $0.035(52)$. & $-0.015(21)$. & $0.044(61)$. & $-0.006(7.2)$ & $0.044(36)$. & $-0.005(6.8)$ & $0.045(43)$. & $-0.004(6.3)$ & 0.044 (50.) \\
\hline$\beta_{2}\left(X^{2}\right)$ & $-0.078(131)$ & -0.048 (36.) & $0.030(21)$. & -0.072 (44.) & $0.006(3.5)$ & $-0.073(24)$. & $0.005(3.1)$ & -0.074 (29.) & $0.005(2.8)$ & -0.071 (34.) \\
\hline$\theta_{6}\left(x_{f}\right)$ & & & & -0.025 (28.) & & $-0.026(14)$. & & $-0.014(5.7)$ & & $-0.015(7.2)$ \\
\hline$\theta_{7}\left(X X_{f}\right)$ & & & & 0.075 (22.) & & 0.078 (10.) & & $0.047(5.7)$ & & $0.048(7.2)$ \\
\hline$\theta_{8}\left(x_{f}^{2}\right)$ & & & & $-0.044(15)$. & & $-0.047(10)$. & & $-0.039(5.6)$ & & $-0.033(5.7)$ \\
\hline$\theta_{9}\left(x_{f} q_{x}\right)$ & & & & & & & & $0.006(5.0)$ & & $0.005(5.1)$ \\
\hline$\theta_{10}\left(X_{x} q_{x}\right)$ & & & & & & & & $-0.011(2.9)$ & & $-0.012(4.2)$ \\
\hline$\theta_{11}\left(x_{f}^{2} a_{x}\right)$ & & & & & & & & $0.008(1.5)$ & & $0.011(2.8)$ \\
\hline$\theta_{12}\left(x_{f}^{2} q_{x}^{2}\right)$ & & & & & & & & $0.003(2.9)$ & & $0.003(3.0)$ \\
\hline$n$ & 588,045 & 136,5 & & & & 136,5 & & 136,5 & & 136,545 \\
\hline$R^{2}$ & 0.30 & 0.19 & & & & 0.28 & & 0.2 & & 0.38 \\
\hline
\end{tabular}

${ }^{\dagger}$ Absolute t-ratio in parentheses where standard errors were obtained by a cluster bootstrap in the regressions that include $q$. The dependent variable is In(weekly earnings). Also included in regressions are five regions of residence indicators and, for models two to five, 47 immigrant country of birth dichotomous variables. For model 5 , nine occupation and nineteen industry indicators are also included in the regression. The estimated returns to the variables in $X^{2} x_{f}{ }^{2}$ and $X x_{f}$ have been multiplied by 100 .

Source: Calculations from statistics Canada 2006 census data. 
Table 3 Estimated returns to years of schooling and years of work experience-Females ${ }^{\dagger}$

\begin{tabular}{|c|c|c|c|c|c|c|c|c|c|c|}
\hline \multirow[t]{2}{*}{ Variables } & \multirow[t]{2}{*}{$\begin{array}{l}\text { Canadian } \\
\text { born (1) }\end{array}$} & \multicolumn{2}{|c|}{$\begin{array}{l}\text { Model } 1 \text { (no difference in } \\
\text { quality) }\end{array}$} & \multicolumn{2}{|c|}{$\begin{array}{c}\text { Model } 2 \text { (Model } 1+\text { country of birth schooling }+ \\
\text { country of birth work experience }+ \text { country of birth } \\
\text { fixed effects) }\end{array}$} & \multicolumn{2}{|c|}{$\begin{array}{c}\text { Model } 3 \text { (Model } 2+\text { direct } \\
\text { effect of } q \text { ) }\end{array}$} & \multicolumn{2}{|c|}{$\begin{array}{c}\text { Model } 4 \text { (Model } 3+\text { interaction } \\
\text { effects of } q \text { ) }\end{array}$} & \multirow{2}{*}{$\begin{array}{c}\text { Model 5 } \\
\text { (Model } 4+ \\
\text { occupation } \\
\text { and } \\
\text { industry } \\
\text { indicators) }\end{array}$} \\
\hline & & Immigrants (2) & (2) - (1) & Immigrants (3) & (3) - (1) & Immigrants (4) & (4) - (1) & Immigrants (5) & (5) - (1) & \\
\hline$\overline{a_{1}(S)}$ & $0.105(320)$ & $0.079(118)$ & -0.026 (35.) & $0.083(112)$ & $-0.022(27)$. & $0.083(112)$ & -0.022 (28.) & $0.086(114)$ & $-0.020(24)$. & 0.057 (57.) \\
\hline$\theta_{1}\left(q_{1}\right)$ & & & & & & $0.020(4.4)$ & & $-0.006(1.2)$ & & $-0.015(2.6)$ \\
\hline$\theta_{2}\left(s_{f}\right)$ & & & & $-0.003(7.4)$ & & $-0.003(7.5)$ & & $-0.002(4.3)$ & & $-0.001(2.6)$ \\
\hline$\theta_{3}\left(s_{f} q_{s}\right)$ & & & & & & & & $0.002(7.6)$ & & $0.003(8.4)$ \\
\hline$\theta_{4}\left(s_{f} f_{\text {dip }}\right)$ & & & & $-0.006(21)$. & & -0.006 (21.) & & $-0.001(1.8)$ & & $.0004(0.7)$ \\
\hline$\theta_{5}\left(s_{f} f_{d i p} q_{s}\right)$ & & & & & & & & 0.004 (12.) & & $0.002(7.6)$ \\
\hline$\beta_{1}(X)$ & $0.042(164)$ & 0.028 (44.) & $-0.015(22)$. & 0.039 (57.) & $-0.003(4.7)$ & 0.039 (57.) & $-0.002(3.0)$ & $0.040(57)$. & $-0.003(3.7)$ & $0.036(45)$. \\
\hline$\beta_{2}\left(X^{2}\right)$ & $-0.066(112)$ & -0.037 (28.) & 0.029 (21.) & -0.061 (39.) & $0.005(2.9)$ & -0.061 (40.) & $0.003(1.5)$ & -0.061 (39.) & $0.004(2.7)$ & -0.056 (32.) \\
\hline$\theta_{6}\left(x_{f}\right)$ & & & & -0.026 (26.) & & $-0.026(26)$. & & $-0.017(9.9)$ & & $-0.017(8.2)$ \\
\hline$\theta_{7}\left(X X_{f}\right)$ & & & & 0.080 (23.) & & 0.081 (23.) & & $0.043(7.7)$ & & $0.044(6.6)$ \\
\hline$\theta_{8}\left(x_{f}^{2}\right)$ & & & & $-0.044(15)$. & & $-0.045(15)$. & & $-0.023(4.1)$ & & $-0.020(3.7)$ \\
\hline$\theta_{9}\left(x_{f} q_{x}\right)$ & & & & & & & & $0.004(4.3)$ & & $0.003(2.8)$ \\
\hline$\theta_{10}\left(X_{x} q_{x}\right)$ & & & & & & & & $-0.018(7.1)$ & & $-0.016(5.0)$ \\
\hline$\theta_{11}\left(x_{f}^{2} a_{x}\right)$ & & & & & & & & $0.023(6.2)$ & & $0.019(4.8)$ \\
\hline$\theta_{12}\left(x_{f}^{2} q_{x}^{2}\right)$ & & & & & & & & $0.005(5.7)$ & & $0.003(3.8)$ \\
\hline$n$ & 499,055 & 113,4 & & & & 113,4 & & 113,4 & & 113,445 \\
\hline$R^{2}$ & 0.31 & 0.20 & & & & .28 & & 0.2 & & 0.39 \\
\hline
\end{tabular}

${ }^{\dagger}$ Absolute t-ratio in parentheses where standard errors were obtained by a cluster bootstrap in the regressions that include $q$. The dependent variable is In(weekly earnings). Also included in regressions are five regions of residence indicators and, for models two to five, 47 immigrant country of birth dichotomous variables. For model 5, nine occupation and nineteen industry indicators are also included in the regression. The estimated returns to the variables in $X^{2} x_{f}{ }^{2}$ and $X x_{f}$ have been multiplied by 100 .

Source: Calculations from statistics Canada 2006 census data. 


\subsection{Relative GDP as a human capital quality indicator}

Model 2 is not that useful for estimating the impact of human capital quality on the immigrant wage gap along the lines discussed in Section 2 as it pre-supposes that the effect of quality of schooling and work experience on immigrant earnings is the same for all countries of birth, which is clearly untenable, especially since results in international standardized literacy tests vary across countries. Model 3, Model 4 and Model 5 correct for that by introducing Relative GDP per capita as a human capital quality indicator $^{11}$. Model 3 allows for human capital quality to affect earnings only directly (à la Borjas, 1987; Akbari, 1996 and Hanushek and Kimko, 2000) while Model 4 and Model 5 allow for human capital quality to affect earnings both directly and indirectly through the returns to years of schooling and years of work experience. Specifically, Model 3 corresponds to equation ( 7 ) but with the restriction $\left(\theta_{3}=\theta_{5}=\theta_{9}=\theta_{10}=\theta_{11}=\theta_{12}=0\right)$ while Model 4 and Model 5 correspond to equation (7) without restriction. Model 4 and Model 5 differ by the control variables that are included in the vector $y$. Model 4 includes province of residence, language skill and marital status. Model 5 adds to the above 9 occupation and 19 industry indicators. While incorporating occupation and industry variables in wage regressions is often frowned upon when performing BlinderOaxaca type decompositions (because of the possibility of endogenetiy between salary, occupation and industry), doing so could be useful in our case to test the robustness of our results ${ }^{12}$.

Looking at the coefficient estimates of Model 3 in Table 2 and Table 3, we find that the direct impact of Relative GDP per capita on immigrant wages is rather small (although statistically significant). Specifically, we find that an immigrant's wage elasticity with respect to this variable is 0.042 for males ( 0.018 for females), which is actually smaller than the value of 0.116 found in Borjas (1987). This suggests, for example, that a male immigrant from a country whose GDP per capita level is 10 percent that of Canada (e.g., India) earns about 9.7 percent less than another immigrant who comes from a country whose per-capita GDP is comparable to that of Canada, but who is similar in all other respects. The equivalent figure for female immigrants is 4.6 percent.

While the results of Model 3 show that Relative GDP per capita has a positive direct impact on immigrants' wages, we are concerned that Relative GDP per capita may be capturing more than a human capital quality effect. Indeed it could be capturing the effects of a host of other factors beside quality of schooling and of work experience, such as, for example, an immigrant self-selection effect (Borjas, 1987).

The coefficient estimates of Model 4 and Model 5 in Table 2 and Table 3 provide a more convincing argument that Relative GDP per capita is an appropriate indicator of human capital quality. Indeed, we find that the effects of Relative GDP per capita on immigrants' earnings seem to be mostly operating through the Years of schooling and Years of work experience variables: the interaction effects of Relative GDP per capita are all highly statistically significant and of the expected signs (that is, they are positive). However, the direct impact of Relative GDP per capita is much smaller than in Model 3 and is actually statistically insignificant in Model 4, which suggest that there may not be a self-selection effect of the type discussed in Borjas (1987).

Overall, Model 4 and Model 5 estimate that human capital acquired in a rich country is valued significantly more than human capital acquired in a poor country. For male immigrants in Model 4, schooling acquired in a country whose GDP per capita is similar to that 
of Canada has a rate of return that is 1.6 percent per year higher than that acquired in a country whose GDP per capita is one-tenth that of Canada ${ }^{13}$. The equivalent figure for work experience is 0.8 percent $^{14}$. The results for female immigrants are similar.

A puzzling result though concerns the returns to human capital acquired in Canada. While the return to work experience for immigrants (whether male or female) is roughly the same as that for Canadian born individuals if the work experience has been acquired in Canada, which is what we should expect, the return to schooling acquired in Canada in Model 4 is 1.0 percent per year lower for male and 2.0 percent per year lower for female immigrants than for their native counterparts. This may reflect Schaafsma and Sweetman's (2001) contention that the outcome of education acquired by immigrants in Canada may be lower because of "acculturation". In our case, the impact of acculturation would appear to be not only in terms of levels of attainment but also in terms of returns. More research is needed in that regard ${ }^{15}$.

Another interesting observation comes from comparing, for immigrants, the return to human capital acquired in Canada with that acquired in birth countries with GDP per capita similar to that of Canada. If the estimated returns to schooling and to work experience truly reflect the value of these skills (and are not reflective of other factors such as labor market discrimination), and if GDP per capita is a complete measure of human capital quality, then we should expect the rates of return on schooling and work experience acquired in Canada to be the same as those on schooling and work experience acquired in countries whose GDP per capita are similar to that of Canada. This is not, however, what we observe. The return per year of schooling acquired in a country whose GDP per capita is similar to that of Canada ${ }^{16}$ is about 0.8 percent lower for males (2.3 percent lower for females) than for schooling acquired in Canada, and the return to work experience is about 1.5 percent per year lower (1.8 percent compared with 3.3 percent for males and 1.3 percent compared with 2.8 percent for females) ${ }^{17}$.

Finally, we would be remiss if we did not mention that controlling for human capital quality significantly reduces the magnitude of the language skill coefficients in the wage regressions. For example, compared to only knowing English, the penalty for not knowing any official language for male immigrants goes from -35.7 percent in Model 1 to -14.9 percent in Model 4 (see Table B1 in Appendix B). The equivalent figures are respectively -24.2 percent and -9.4 percent for females. This suggests that the role of language skills in explaining the immigrant wage gap may not be as large as what has been estimated in previous studies-much of it may just have been reflecting lower schooling and work experience quality.

\subsection{Results from the Blinder-Oaxaca decomposition}

In this section, we look at the contribution of differences in human capital quality to the immigrant wage gap using the decomposition (8). Table 4 reports selected elements of that decomposition estimated using Model 1 (which does not accounts for human capital quality) and Model 4 (our preferred specification, which accounts for human capital quality while bypassing the possible endogeneity problems following the introduction of occupation and industry variables in the regression) ${ }^{18}$. As has been noted elsewhere (see, for example, Nadeau and Seckin, 2010), a key reason why Canadian immigrants earn less on average than natives is not because they have fewer years of 
Table 4 Decomposition of Immigrant Wage Gaps

\begin{tabular}{|c|c|c|c|c|c|c|c|c|}
\hline & \multicolumn{4}{|c|}{ Males } & \multicolumn{4}{|c|}{ Females } \\
\hline & \multicolumn{2}{|c|}{ Model 1} & \multicolumn{2}{|c|}{ Model 4} & \multicolumn{2}{|c|}{ Model 1} & \multicolumn{2}{|c|}{ Model 4} \\
\hline & $\begin{array}{l}\text { Wage } \\
\text { gap }\end{array}$ & $|t|$ & $\begin{array}{l}\text { Wage } \\
\text { gap }\end{array}$ & $|t|$ & $\begin{array}{l}\text { Wage } \\
\text { gap }\end{array}$ & $|t|$ & $\begin{array}{l}\text { Wage } \\
\text { gap }\end{array}$ & $|t|$ \\
\hline Observed gap $^{a}$ & -0.041 & 20.0 & -0.041 & 20.0 & -0.033 & 16.4 & -0.033 & 16.4 \\
\hline Explained gap & 0.156 & 109. & 0.156 & 109. & 0.115 & 71.3 & 0.115 & 71.3 \\
\hline Schooling & 0.059 & 78.8 & 0.059 & 78.8 & 0.027 & 27.9 & 0.027 & 27.9 \\
\hline Work experience & 0.032 & 59.7 & 0.032 & 59.7 & 0.033 & 61.7 & 0.033 & 61.7 \\
\hline Language & 0.004 & 3.61 & 0.004 & 3.61 & -0.001 & 0.75 & -0.001 & 0.75 \\
\hline Others $^{b}$ & 0.061 & 87.2 & 0.061 & 87.2 & 0.056 & 85.0 & 0.056 & 85.0 \\
\hline Unexplained gap & -0.197 & 91.4 & -0.074 & 5.49 & -0.148 & 67.0 & -0.002 & 0.19 \\
\hline Schooling & -0.184 & 19.2 & -0.141 & 8.50 & -0.363 & 34.9 & -0.272 & 18.3 \\
\hline Work experience & -0.147 & 19.1 & -0.064 & 5.68 & -0.148 & 20.2 & -0.041 & 4.23 \\
\hline Language & 0.025 & 2.18 & -0.008 & 0.67 & 0.006 & 0.48 & -0.017 & 1.43 \\
\hline Others $^{c}$ & 0.109 & 6.21 & 0.139 & 5.24 & 0.357 & 19.6 & 0.329 & 14.0 \\
\hline Immigrant specific effects & & & -0.124 & 9.92 & & & -0.145 & 18.3 \\
\hline Country of birth fixed effects & & & 0.022 & 9.18 & & & 0.015 & 6.75 \\
\hline Human-capital quality (total) & & & -0.147 & 12.2 & & & -0.160 & 17.6 \\
\hline Country of birth's GDP direct effect & & & 0.007 & 0.69 & & & 0.010 & 1.22 \\
\hline Schooling quality (total) & & & -0.077 & 9.62 & & & -0.105 & 17.8 \\
\hline Years of foreign schooling & & & -0.008 & 0.73 & & & -0.025 & 3.66 \\
\hline Foreign diploma fixed effects & & & 0.017 & 4.07 & & & -0.005 & 1.33 \\
\hline $\begin{array}{l}\text { Country of birth's GDP education } \\
\text { effect }\end{array}$ & & & -0.087 & 12.1 & & & -0.075 & 14.4 \\
\hline Work experience quality (total) & & & -0.076 & 21.2 & & & -0.065 & 27.3 \\
\hline Years of foreign work experience & & & -0.046 & 6.90 & & & -0.057 & 11.6 \\
\hline $\begin{array}{l}\text { Country of birth's GDP work } \\
\text { experience effect }\end{array}$ & & & -0.030 & 4.69 & & & -0.007 & 1.58 \\
\hline
\end{tabular}

${ }^{a}$ Difference between the log of weekly earnings of immigrants and that of Canadian born workers.

${ }^{\mathrm{b}}$ The category Others include the Region of residence, Urban area, Married and the Constant term variables.

'The large contribution of the Others set of variables to the female immigrant wage gap is mostly due to the large

difference between the estimated constant term coefficient in the immigrant female regression and that in the Canadian born female regression (see Table B 2 in Appendix B).

schooling or fewer years of work experience than natives, but because their returns to schooling and work experience are much lower than those enjoyed by natives. Indeed, based on observed characteristics alone, Canadian male immigrants should earn 15.6 percent more than natives, but, mostly because of lower returns to schooling and work experience, in the end, they earn 4.1 percent less than natives (the equivalent figures are respectively 11.5 percent and 3.3 percent for female immigrants). It is also interesting to note that between the differential return to schooling and the differential return to work experience, it is the differential return to schooling that accounts for a larger share of the immigrant wage gap. In fact, the contribution of the differential return to schooling to the immigrant wage gap is about 35 percent larger than that of work experience for males, and about 150 percent larger for females.

A number of explanations have been proposed to account for the lower returns to schooling and work experience earned by immigrants compared to natives, including lower quality of skills and labor market discrimination. A key objective of this paper is to 
put a figure on the impact of the former. According to the Model 4 estimates in Table 4, lower human capital quality is by far the major reason why immigrants earn less than natives. In fact, we find that after controlling for quality, the share of the immigrant wage gap explained by the differential return to schooling drops by almost 25 percent for both males and females (from -0.184 to -0.141 for males and from -0.363 to -0.272 for females). The drop in the share of the immigrant wage gap explained by the differential return to work experience is even more dramatic: it is of about 56 percent for males (from -0.147 to -0.064 ) for males and of almost 72 percent for females (from -0.148 to -0.041 ).

Overall, we find that the lower quality of schooling and of work experience more than negates the endowment advantage that immigrants have in these areas. Indeed, based on observed years of schooling and observed years of work experience alone, male immigrants should earn 9.1 percent more than natives, but lower quality of schooling and work experience subtracts 15.3 percent from that (the equivalent figures are respectively 6.0 percent and 17.0 percent for female immigrants). Of the total human capital quality effect, 75 percent is accounted for by differences in GDP per capita for males and 50 percent for females.

It is also noteworthy that unlike other studies (see, for example, Aydemir and Skuterud, 2005; Nadeau and Seckin, 2010), we find that the role of language skills in explaining the immigrant wage gap is rather small. As a point of comparison, we find that the share of the immigrant wage gap explained by differences in human capital quality is more than 35 times that explained by language skills (both in terms of endowments and returns) for males and about nine times for females.

Finally, we observe that after controlling for human capital quality, the unexplained component of the wage gap (which is sometimes associated with labor market discrimination) is reduced by about 62 percent for male immigrants and virtually eliminated for female immigrants. This reinforces the point made in Bonikowska, Green and Riddell (2008) that what is sometimes blamed on labor market discrimination may just reflect lower human capita quality ${ }^{19}$.

\section{Conclusion}

This paper addresses the issue of measuring the human capital quality of immigrants. First, borrowing from the economic development literature, we propose a methodology that uses GDP per capita in an immigrant's country of birth interactive variables in a Mincerian regression framework to measure the quality of schooling and work experience acquired in that country. Next, we use this methodology to measure the contribution of differences in human capital quality to the immigrant-native wage gap in Canada.

Results reveal that GDP per capita is a good indicator of human capital quality. For one, we find that the returns to schooling and work experience significantly increase with the GDP per capita of an immigrant's country of birth, even when incorporating country of birth fixed effects and occupation and industry variables in the regression. In particular, we find that schooling and work experience acquired in a country whose GDP per capita is similar to that of Canada have rates of return that are respectively 1.6 percent and 0.8 percent per year higher than schooling and work experience acquired in a country whose GDP per capita is one-tenth that of Canada (schooling and work experience acquired in India for example). 
With regards to measuring the contribution of human capital quality to the immigrant wage gap in Canada, we find that lower human capital quality completely negates the endowment advantage that immigrants have in the areas of schooling and work experience and is by far the major reason why they earn less than Canadian natives. In particular, we estimate that the share of the immigrant wage gap explained by differences in human capital quality is more than 35 times that explained by language skills (both in terms of endowments and returns) for males and about nine times for females. Finally, we observe that after controlling for human capital quality, the unexplained component of the wage gap (which is sometimes associated with labor market discrimination) is reduced by almost 62 percent for male immigrants and virtually eliminated for female immigrants.

This study has important implications. From an analytical point of view, it suggests that the worsening of the immigrant wage gap in Canada over the last couple of decades may not be due so much to a geographic shift in immigrant source countries (from the U.S., England and other countries in Western Europe to countries in Asia and North Africa), but rather to an economic shift in immigrant source countries from relatively rich to relatively poor countries. From a policy point of view, this study suggests that if a country wants to adopt an immigrant selection policy based on a point system such as that of Canada, then for the same number of years of schooling and of work experience, the number of points should vary depending on the assessed quality of those years of schooling and work experience. In particular, more points should be allocated if schooling (especially the highest diploma) and work experience have been acquired in Canada than if they have been acquired in another country. Another and possibly more efficient approach, would be to rely less on the number of years of schooling and of work experience in selecting immigrants, and more on cognitive and professional accreditation tests.

\section{Endnotes}

${ }^{1}$ For example, data on GDP adjusted for purchasing power parity (PPP) are available for as many as 188 countries and 55 years in Heston, Summers and Aten (2009).

${ }^{2}$ There are some exceptions to this, however. For example, Bratsberg and Terrell (2002) examine the impact of birth country school quality on the returns to education of U.S. immigrants and find that differences in the attributes of educational systems account for most of the variation in rates of return to education earned by immigrants. There are also a number of studies of the labor market integration of Canadian immigrants that recognize that schooling and work experience acquired outside Canada may be of lower quality than that acquired in Canada and may yield lower returns (see, for example, Schaafsma and Sweetman, 2001 and Bonikowska, Green and Riddell, 2008). However, the ways to empirically measure the impact of differences in human capital quality on the immigrant wage gap have typically been over-simplistic. Indeed, a common approach has been to assume that the returns to human capital (be it to schooling or to work experience) acquired outside Canada differ from that acquired in Canada, but is the same irrespective of the country where it has been acquired (see, for example, Frenette and Morissette, 2005, Aydemir and Skuterud, 2005 and Nadeau and Seckin, 2010).

${ }^{3}$ Nevertheless, Li and Sweetman (2014) use the index developed by Hanushek and Kimko (2000) as an indicator of education quality. They study the impact of the quality of education in the source country on the rate of return to education of immigrants in Canada. They find, like we do using a different approach, that the impact is important. 
${ }^{4}$ For example, Cawley, Heckman and Vytlacil (2001) find that measured cognitive ability is almost perfectly correlated with years of schooling.

${ }^{5}$ Another paper that uses GDP per capita as a measure of human capital quality is Akbari (1996). Unlike his paper. however, our paper distinguishes between quality of schooling and quality of work experience.

${ }^{6}$ Another variable that could have been used as a measure of human capital quality instead of GDP per capita is labor productivity. The problem though is that data on labor productivity are not as widely available and as reliable as data on GDP per capita.

${ }^{7}$ As pointed out by referees and other commentators, the ratio of GDP per capita that we use may reflect other things than quality of human capital. The alternative explanations include differences in self-selection of immigrants, skill transferability and capital intensity. Those issues are addressed explicitly and several tests are provided in our other paper (Coulombe, Grenier and Nadeau, 2014, section 5). While those other explanations cannot be excluded completely, we conclude that "the relationship between the returns to immigrant human capital and country of birth income that we observe is most consistent with a model where the quality of human capital in a country is positively related with that country's level of income".

${ }^{8}$ Since the quality variable is taken at the country level over time, the problem of macro variables in micro regressions may arise since the errors could be correlated within groups (see Moulton, 1990). This may lead to inconsistent estimates of the standard errors. Several approaches have been proposed to address that problem (see, for example, Cameron et al. 2008 and MacKinnon and Webb 2013). Here we used a cluster robust variance estimator and a cluster bootstrap to estimate the standard errors of the coefficients (in addition to a robust standard error estimator that ignores clustering). The statistical significance is almost the same whathever method is used and the economic interpretation is not changed. The results reported in the tables are those of the cluster bootstrap.

${ }^{9}$ Excluding workers who have not obtained their highest certificate, degree or diploma in either Canada or their country of birth reduce the sample sizes by about one percent for Canadian born individuals and five percent for immigrants.

${ }^{10}$ Since the model is non-linear with respect to work experience, those marginal returns are calculated from the coefficients of Model 2 at 10 years of work experience.

${ }^{11}$ Note that Relative GDP per capita is not perfectly collinear with country of birth fixed effects in our regression since Relative GDP per capita is measured at the time of immigration, which means that it not only varies across countries of birth but also across immigrants.

${ }^{12}$ Indeed, one could argue that the relationship we observe between GDP per capita and the returns to schooling and work experience is just an artefact of having omitted variables in our regression such as occupation and industry-the argument being that immigrants may be overrepresented in low earning occupation and low earning sectors and that the likelihood of immigrants ending up in these occupations and sectors may be somehow related to the GDP per capita in their country of birth. Our data do not allow to compare the occupation prior and after immigration, but there is some evidence that many immigrants after they arrive must work in an occupation that has a lower status than the one that they previously had or intend to have; some may remain without work while waiting for a job in the desired occupation (see, for example, Chiswick, Lee and Miller, 2005; and Grenier and 
Xue, 2011). However, there is no evidence that the problem is greater for immigrants from poor countries than for immigrants from rich countries (see Lagakos et al. 2014 for the case of the U.S.). Nevetheless, it is interesting to note that the variables related to GDP per capita are still significant in the expanded specification (even more so than before for a number of them).

${ }^{13}$ This figure is calculated as the difference between the derivative of equation (7) with respect to $s_{f}$ evaluated at the coefficients of Model $4, f_{\text {dip }}=1$ and $q=0$ and that evaluated at the coefficients of Model 4, $f_{d i p}=1$ and $q=\ln (0.1)$.

${ }^{14}$ This figure is calculated as the difference between the value of an additional year of work experience when $q=0$ and that when $q=\ln (0.1)$. The value of an additional year of experience is calculated as the difference between Equation (7) evaluated at the coefficients of Model 4 and the mean value of work experience of the natives and that of Equation (7) evaluated at the coefficients of Model 4 and the mean value of work experience of the natives plus one, holding all other variables constant. Note that for this calculation $X$ is set equal to $x_{f}{ }^{15}$ Differences in literacy and educational quality may be relevant, as shown by Ferrer, Green and Riddell (2006).

${ }^{16}$ This figure is calculated as the derivative of equation (7) with respect to $s_{\text {If }}$ evaluated at the coefficients of Model 4, $f_{d i p}=1$ and $q=0$. Note that for this calculation $S$ is set equal to $s_{f}$

${ }^{17}$ This figure is calculated as the difference between the value of an additional year of work experience when $x=0$ and that when $q=0$. The calculation of the value of an additional year of experience is explained in footnote 7.

${ }^{18}$ As shown in Oaxaca and Ransom (1999), the detailed decomposition of the unexplained component in (8) is not invariant to the choice of reference groups when dichotomous variables are used in the regression equations. To solve this problem, we follow Gardeazabal and Ugidos (2004) and Yun (2005) and restrict the sum of the estimated coefficients of each set of dichotomous variables to zero in performing the decomposition (8).

${ }^{19}$ Besides the unexplained component of the wage gap, the effects of discrimination could be picked up by the Country of birth fixed effects. However, the contribution of this variable to the immigrant wage gap is positive (see Table 4), which is inconsistent with discrimination. The fact that this variable is positive also raises doubt about the extent of the lack of recognition of foreign credentials as an explanation for the immigrant wage gap (we would expect this variable to be negative if the lack of recognition of foreign credentials was systematic and significant in explaining the immigrant wage gap).

\section{Appendix A. data description Dependent variable}

Our dependent variable is the natural logarithm of weekly earning. Weekly earning is calculated as wages and salaries reported for 2005 divided by the number of weeks worked in 2005.

Some restrictions were applied to eliminate very small and very large values of earnings. Observations with annual wages less than $\$ 1000$ and less than $\$ 2$ per hour in the reference week were removed. The sample was also restricted to individuals who had obtained their (post-secondary) highest certificate, diploma or degree in their country of birth or in Canada according to the Location of study variable in the 2006 census. In the census, the variable location of study is reported only for 
Table A1 Construction of number of years of schooling variable

\begin{tabular}{ll}
\hline Highest certificate, degree or diploma obtained & Estimated years of schooling \\
\hline No certificate & 8 \\
High school certificate & 12 \\
Trade, apprenticeship, college or CEGEP certificates or diploma & 13 \\
from a program of three months to less than one year & 14 \\
Trade, apprenticeship, college or CEGEP certificates or diploma & 15 \\
from a program of one year to two years & 16 \\
University certificate or diploma below bachelor level & 17 \\
University bachelor level & 18 \\
University certificate or diploma above bachelor level & 22 \\
Masters & \\
Doctorate (including medicine, dentistry and similar programs) &
\end{tabular}

individuals who have completed a postsecondary certificate, diploma or degree. For individuals without post-secondary certificate, diploma or degree, we assumed that they had acquired their education in their country of birth except if they had immigrated to Canada before they turned 18, in which case we assumed they had completed their education in Canada.

\section{Independent variables}

We allow earnings to vary across Canadian regions with fixed effects. We control for six regions: the Atlantic Provinces, Quebec, Ontario (the reference category), the Prairies, Alberta and British Columbia.

The 2006 census does not provide a value for Years of schooling. To compute this value we use the information provided on the highest certificate, degree or diploma obtained in the way described in Table A1.

Potential experience is defined as Age minus Years of schooling minus 6. Foreign experience is measured as potential experience minus Years since migration, where Years since migration is calculated as 2005 minus the year the individual's year of immigration (that is, the year landed immigrant status was first granted). Domestic experience is defined as potential experience minus foreign experience.

For language skill, we use the variable Knowledge of the official languages (as evaluated by the respondents). The categories are (1) English only (the reference), (2) French only, (3) Both English and French, and (4) None of English and French.

Relative GDP is measured as the ratio of a ten-year moving average of an immigrant's country of birth real GDP per capita and that of Canada. The moving average is taken to eliminate the variability due to business cycles. Data on real GDP per capita come from Heston, Summers and Aten (2009) and is available for 188 countries (including Canada) and up to 55 years for some countries. Immigrants whose country of birth is not one of these countries are excluded from the regressions. In instances where data on real GDP per capita are not going far enough back in time, Relative GDP is set equal to that of the earliest year available.

In some regressions, we used countries of birth as separate fixed effects. In those instances, we classified the countries as in Grenier and Nadeau (Grenier and Nadeau 2011) where 48 countries or groups of countries are selected according to their importance as sources of immigration. 


\section{Appendix B}

The estimated returns to years of schooling and work experience from the Canadian born earnings equation (6) and the immigrant earnings equation (7) were reported in Tables 2 and 3. The estimated coefficients for the other controls are reported in Table B1.

Table B1 Regression coefficients-control variables

\begin{tabular}{|c|c|c|c|c|c|c|c|c|c|c|c|c|}
\hline \multirow[t]{3}{*}{ Variables } & \multirow{2}{*}{\multicolumn{2}{|c|}{$\begin{array}{l}\text { Native } \\
\text { Males } \\
\text { Model } 1\end{array}$}} & \multicolumn{4}{|c|}{ Immigrant Males } & \multirow{2}{*}{\multicolumn{2}{|c|}{$\begin{array}{l}\text { Native } \\
\text { Females } \\
\text { Model } 1\end{array}$}} & \multicolumn{4}{|c|}{ Immigrant Females } \\
\hline & & & \multicolumn{2}{|c|}{ Model 1} & \multicolumn{2}{|c|}{ Model 4} & & & \multicolumn{2}{|c|}{ Model 1} & \multicolumn{2}{|c|}{ Model 4} \\
\hline & Coeff. & $|t|$ & Coeff. & $|t|$ & Coeff. & $|t|$ & Coeff. & $|t|$ & Coeff. & $|t|$ & Coeff. & $|t|$ \\
\hline Constant term & 5.100 & 1007. & 5.478 & 404.1 & 5.343 & 228.2 & 4.617 & 828.9 & 5.144 & 348.5 & 5.001 & 237.5 \\
\hline Atlantic & -0.253 & 87.9 & -0.142 & 9.4 & -0.223 & 14.7 & -0.242 & 87.9 & -0.180 & 12.0 & -0.231 & 15.8 \\
\hline Quebec & -0.145 & 47.1 & -0.273 & 35.2 & -0.227 & 30.0 & -0.154 & 52.3 & -0.252 & 34.5 & -0.21 & 27.3 \\
\hline Prairies & -0.164 & 56.9 & -0.201 & 24.1 & -0.199 & 26.9 & -0.135 & 47.3 & -0.162 & 19.3 & -0.161 & 18.5 \\
\hline Alberta & 0.077 & 27.9 & 0.037 & 6.2 & 0.021 & 3.1 & -0.012 & 4.3 & -0.078 & 9.5 & -0.059 & 9.9 \\
\hline B.C. & -0.042 & 16.1 & -0.077 & 15.7 & -0.098 & 17.8 & -0.054 & 20.6 & -0.072 & 15.5 & -0.080 & 14.2 \\
\hline Urban & 0.029 & 15.6 & -0.134 & 17.0 & 0.002 & 0.2 & 0.071 & 37.0 & -0.053 & 6.4 & 0.040 & 4.8 \\
\hline Married & 0.214 & 127.4 & 0.121 & 28.5 & 0.174 & 38.3 & 0.036 & 23.3 & -0.021 & 5.9 & 0.018 & 5.1 \\
\hline \multicolumn{13}{|c|}{ Knowledge of official languages (Reference category: English only) } \\
\hline French only & -0.087 & 24.7 & -0.089 & 7.4 & -0.105 & 8.7 & -0.073 & 21.7 & -0.038 & 3.2 & -0.041 & 3.3 \\
\hline English \& French & 0.019 & 7.2 & 0.126 & 18.3 & 0.03 & 4.8 & 0.064 & 26.6 & 0.166 & 26.2 & 0.083 & 12.3 \\
\hline None & -0.196 & 4.2 & -0.357 & 27.7 & -0.149 & 7.1 & -0.129 & 2.6 & -0.242 & 21.7 & -0.094 & 7.3 \\
\hline \multicolumn{13}{|c|}{ Countries of birth (Reference category: United States) } \\
\hline Central America & & & & & -0.091 & 4.1 & & & & & -0.103 & 5.7 \\
\hline Haiti & & & & & -0.084 & 3.4 & & & & & -0.029 & 1.4 \\
\hline Jamaica & & & & & -0.065 & 3.4 & & & & & -0.005 & 0.3 \\
\hline Trinidad & & & & & -0.095 & 4.9 & & & & & -0.004 & 0.3 \\
\hline Other Caribbean & & & & & -0.125 & 6.2 & & & & & -0.048 & 2.9 \\
\hline Guyana & & & & & -0.017 & 0.7 & & & & & 0.029 & 1.5 \\
\hline Other S. America & & & & & -0.045 & 2.4 & & & & & -0.064 & 3.9 \\
\hline France & & & & & 0.051 & 2.7 & & & & & 0.027 & 1.6 \\
\hline Germany & & & & & 0.013 & 0.7 & & & & & -0.013 & 0.8 \\
\hline Other W. Europe & & & & & 0.029 & 1.6 & & & & & -0.034 & 2.4 \\
\hline Romania & & & & & 0.085 & 2.8 & & & & & 0.069 & 3.0 \\
\hline Poland & & & & & 0.001 & 0.1 & & & & & -0.050 & 3.1 \\
\hline Ukraine & & & & & -0.092 & 2.9 & & & & & -0.105 & 4.0 \\
\hline Russia & & & & & -0.072 & 2.4 & & & & & -0.096 & 4.1 \\
\hline Hungary & & & & & -0.025 & 0.7 & & & & & -0.046 & 1.6 \\
\hline Other E. Europe & & & & & -0.058 & 1.7 & & & & & -0.032 & 1.6 \\
\hline U.K. & & & & & 0.091 & 5.1 & & & & & 0.041 & 3.9 \\
\hline Other N. Europe & & & & & 0.087 & 3.3 & & & & & 0.053 & 3.0 \\
\hline Greece & & & & & -0.144 & 5.0 & & & & & -0.070 & 3.8 \\
\hline Italy & & & & & 0.045 & 2.6 & & & & & -0.004 & 0.3 \\
\hline Portugal & & & & & 0.076 & 4.3 & & & & & 0.011 & 0.8 \\
\hline Other S. Europe & & & & & 0.059 & 2.8 & & & & & 0.023 & 1.4 \\
\hline West Africa & & & & & 0.030 & 1.1 & & & & & 0.033 & 1.1 \\
\hline East Africa & & & & & 0.015 & 0.6 & & & & & 0.039 & 1.7 \\
\hline
\end{tabular}


Table B1 Regression coefficients-control variables (Continued)

\begin{tabular}{lllll}
\hline Algeria & -0.069 & 2.1 & 0.018 & 0.6 \\
Egypt & 0.093 & 3.1 & 0.071 & 2.5 \\
Morocco & 0.053 & 1.9 & 0.045 & 1.4 \\
Other N. Africa & -0.051 & 1.6 & -0.001 & 0.0 \\
Southern Africa & 0.287 & 8.9 & 0.178 & 6.3 \\
Lebanon & -0.063 & 2.1 & -0.068 & 2.9 \\
Afghanistan & -0.263 & 7.8 & -0.145 & 4.4 \\
Iran & -0.107 & 3.9 & -0.065 & 2.9 \\
Iraq & -0.085 & 2.4 & -0.086 & 2.3 \\
Other W.C. Asia & 0.015 & 0.7 & -0.007 & 0.3 \\
China & -0.014 & 0.4 & 0.052 & 2.3 \\
Hong Kong & -0.104 & 4.3 & 0.034 & 2 \\
South Korea & -0.214 & 6.7 & -0.059 & 2.0 \\
Taiwan & -0.125 & 4.1 & -0.038 & 1.2 \\
Other E. Asia & -0.059 & 1.8 & -0.058 & 1.9 \\
Philippines & -0.122 & 5.9 & -0.030 & 1.7 \\
Vietnam & .0004 & 0.1 & 0.019 & 0.8 \\
Other S.E. Asia & 0.017 & 0.7 & 0.060 & 3.0 \\
India & 0.055 & 2.4 & -0.020 & 1.0 \\
Sri Lanka & -0.082 & 3.7 & -0.099 & 5.0 \\
Pakistan & -0.075 & 2.8 & -0.071 & 2.8 \\
Bangladesh & -0.233 & 7.6 & -0.271 & 7.8 \\
Others & 0.000 & 0.0 & 0.009 & 0.5 \\
\hline & & & & \\
\hline & & &
\end{tabular}

\section{Competing interest}

The IZA Journal of Migration is committed to the IZA Guiding Principles of Research Integrity. The authors declare that they have observed these principles.

\section{Acknowledgement}

We benefited from comments on earlier versions of the paper by Ted McDonald and participants at seminars given at the $46^{\text {th }}$ Conference of the Canadian Economic Association in Calgary, the $50^{\text {th }}$ Conference of the Sociéte canadienne de science économique in Mont-Tremblant, Quebec and at Saint Mary's University, Halifax. We would also like to thank three anonymous referees for their comments.

Responsible editor: Denis Fougere

Received: 1 April 2014 Accepted: 26 June 2014

Published: 31 Jul 2014

\section{References}

Abramovitz M (1956) Resource and output trends in the united states since 1870. Am Econ Rev 46(2):5-23 Akbari A (1996) Provincial income disparities in Canada: Does the quality of education matter. Can J Econ 29:S337-S339 Arrow KJ (1962) The economic implications of learning by doing. Rev Econ Stud 29(1):155-173

Aydemir A, Skuterud M (2005) Explaining the deteriorating entry earnings of Canada's immigrant cohorts, 1966-2000.

Can J Econ 38(2):641-671

Blinder AS (1973) Wage discrimination: reduced form and structural estimates. J Hum Resour 8(4):436-455

Bloom DE, Grenier G, Gunderson M (1995) The changing labour market position of Canadian immigrants. Can J Econ 28(4b):987-1005

Bloom N, Van Reenen J (2007) Measuring and explaining management practices across firms and countries. Q J Econ 122(4):1351-1408

Bloom N, Van Reenen J (2010) Human resource management and productivity. In: Ashenfelter O, Card D (ed)

Handbook of labor economics. Elsevier, Amsterdam, pp 1697-1768

Bonikowska A, Green D, Craig Riddell W (2008) Literacy and the Labour Market: Cognitive Skills and Immigrant Earnings.

Catalogue no. 89-552-M, Research Report No. 20. Statistics Canada, Ottawa

Borjas GJ (1987) Self-selection and the earnings of immigrants. Am Econ Rev 77(4):531-553

Bratsberg B, Terrell D (2002) School quality and returns to education of U.S. Immigrants. Econ Inq 40(2):177-198 
Cameron AC, Gelbach JB, Miller DL (2008) Bootstrap-based improvements for inference with clustered errors. Rev Econ Stat 90(3):414-427

Card D (2005) Is the new immigration really so bad? Econ J 115:F300-F323

Cawley J, Heckman J, Vytlacil E (2001) Three observations on wages and measured cognitive ability. Labour Econ 8 (4):419-442

Chiswick B (1978) The effect of Americanization on the earnings of foreign-born men. J Polit Econ 86(5):897-921

Chiswick B, Lee Y, Miller P (2005) A longitudinal analysis of immigrant occupational mobility: a test of the immigrant assimilation hypothesis. Int Migr Rev 39(2):332-353

C S, Tremblay J-F (2009) Migration and skills disparities across the Canadian provinces. Reg Stud 43(1):5-18

Coulombe S, Grenier G, Nadeau S (2014) Quality of work experience and economic development—estimates using Canadian immigrant data. J Hum Cap 8(3). ahead of print

Coulombe S, Tremblay J-F, Marchand (2004) Literacy Scores, Human Capital and Growth across Fourteen OECD Countries. Statistics Canada, Ottawa

Erosa A, Koreshkova T, Restucia D (2010) How important is human capital? a quantitative theory assessment of world income inequality. Rev Econ Stud 77(4):1421-1449

Ferrer A, Green DA, Craig Riddell W (2006) The effect of literacy on immigrant earnings. J Hum Resour 41(2):380-410

Frenette M, Morissette R (2005) Will they ever converge? earnings of immigrant and Canadian-born workers over the last two decades. Int Migr Rev 39(1):228-257

Gardeazabal J, Ugidos A (2004) More on identification in detailed wage decompositions. Rev Econ Stat 86(4):1034-1036

Grenier G, Nadeau S (2011) Immigrant access to work in Montreal and Toronto. Canad J Reg Sci/Revue canadienne des sciences régionales 34(1):19-33

Grenier G, Xue L (2011) Canadian Immigrants' Access to a First Job in Their Intended Occupation. J Int Migr Integr 12(3):275-303

Hanushek EA, Kimko DD (2000) Schooling, labor-force quality, and the growth of nations. Am Econ Rev 90(5):1184-1208

Hanushek EA, Woessmann L (2008) The role of cognitive skills in economic development. J Econ Lit 46(3):607-668

Heston A, Summers R, Aten B (2009) Penn World Table Version 6.3. Center for International Comparisons of Production, Income and Prices. University of Pennsylvania

Lagakos D, Moll B, Porzio T, Qian N (2012) Experience matters: human capital and development accounting. Manuscript, Princeton University, Princeton, New Jersey

Lagakos D, Porzio BM, Qian N, Schoelman T (2014) Lifecycle Human Capital Accumulation across Countries: Lessons from U.S. Immigrants. Manuscript. Arizona State University, Phoenix, Arizona

Li Q, Sweetman A (2014) The quality of immigrant source country educational outcomes: Do they matter in the receiving country?". Labour Econ 20:81-93

Mackinnon JG, Webb MD (2013) "Wild Bootstrap Inference for Wildly Different Cluster Sizes" Queen's Economics Department Working Paper No. 1314. Kingston, Ontario

Manuelli R, Seshadri A (2010) Human Capital and the Wealth of Nations, Manuscript. University of Wisconsin-Madison, Madison, Wisconsin

Moulton BR (1990) An Illustration of a Pitfall in Estimating the Effects of Aggregate Variables on Micro units". Rev Econ Stat 72:334-338

Nadeau S, Seckin A (2010) The immigrant wage Gap in Canada: Quebec and the rest of Canada. Canad Public Policy/ Analyse de politiques 36(3):265-285

Oaxaca R (1973) Male-female wage differentials in urban labour markets. Int Econ Rev 14(3):693-709

Oaxaca RL, Ransom MR (1999) Identification in detailed wage decomposition. Rev Econ Stat 81(1):154-157

Oreopoulos P (2009) Why Do Recent Immigrants Struggle in the Labour Market? A Field Experiment with 6,000 Resumes, Working Paper No. 09-03. Metropolis British Columbia, Centre of Excellence for Research on Im migration and Diversity, Vancouver

Reitz JG (2005) Tapping Immigrants' skills: New directions for Canadian immigration policy in the knowledge economy. IRPP choices, vol 11(1). Montreal, Quebec

Romer P (1986) Increasing returns and long-Run growth. J Polit Econ 94(5):1002-1037

Schaafsma J, Sweetman A (2001) Immigrants earnings: Age at immigration matters. Can J Econ 34(4):1066-1099

Smith JP (2006) Immigrants and the labor market. J Labor Econ 24(2):203-233

Sweetman A (2004) Immigrant Source Country Educational Quality and Canadian Labour Market Outcomes Catalogue. No. 11F0019MIE Research Report No. 234. Statistics Canada, Ottawa

Times Higher Education (2012) Times Higher Education World University Rankings 2011-2012. http://www.timeshighereducation.co.uk/world-university-rankings/

Yun M-S (2005) A simple solution to the identification problem in detailed wage decompositions. Econ Inq 43(4):766-772

10.1186/2193-9039-3-14

Cite this article as: Coulombe et al:: Human capital quality and the immigrant wage gap. IZA Journal of Migration 2014, 3:14 